\title{
Wartość hodowlana wybranych odmian jabłoni (Malus domestica) pod względem odporności na parcha i mączniaka jabłoni
}

\author{
Breeding value of selected apple cultivars (Malus domestica) for the resistance \\ to apple scab and powdery mildew
}

Mariusz Lewandowski® ${ }^{\circledast y l w i a ~ K e l l e r-P r z y b y ł k o w i c z ~}{ }^{\oplus}$

Zakład Hodowli Roślin Ogrodniczych,

Instytut Ogrodnictwa, ul. Konstytucji 3 Maja 1/3, 96-100 Skierniewice,

$\triangle$ e-mail: mariusz.lewandowski@inhort.pl

\begin{abstract}
Celem badań była ocena przydatności kilku odmian jabłoni do hodowli nowych genotypów odpornych/mało podatnych na parcha i mączniaka jabłoni w oparciu o ich ogólną (GCA) i specyficzną zdolność kombinacyjną (SCA). Stopień porażenia siewek jabłoni, stanowiących potomstwo 11 genotypów jabłoni, krzyżowanych w układzie czynnikowym: $94 \times § 7-4$ odmiany mateczne ('Alwa', 'Golden Delicious', 'Free Redstar', 'Gold Milenium') i 7 odmian ojcowskich ('Glogierówka', 'Kronselka', 'Kosztela', 'McIntosh', 'Oliwka Żółta', 'Malinowa Oberlandzka', 'Koksa Pomarańczowa') przez oba patogeny oceniono w lipcu 2019 r. Istotnie ujemną wartość efektu GCA dla stopnia porażenia siewek przez parcha jabłoni oszacowano dla odmiany 'Free Redstar'. Wskazuje to, że odmiana ta jest donorem genów warunkujących 'odporność' lub małą podatność na parcha jabłoni u potomstwa. Istotnie ujemną wartość efektu GCA dla stopnia porażenia siewek przez mączniaka jabłoni oszacowano dla odmiany ‘Free Redstar'. Oznacza to, że genotyp ten jest donorem genów warunkujących 'odporność' lub małą podatność na mączniaka jabłoni u siewek. Negatywne efekty SCA dla stopnia porażenia siewek przez parcha jabłoni uzyskano dla 3 rodzin mieszańców: 'Free Redstar' × 'McIntosh', 'Alwa' $\times$ 'Malinowa Oberlandzka' i 'Alwa' $\times$ 'McIntosh'. Oznacza to, że w przypadku tych rodzin genetyczne współdziałanie obu genotypów rodzicielskich warunkuje 'odporność' lub małą podatność roślin na parcha jabłoni.
\end{abstract}

Słowa kluczowe: jabłoń, Malus domestica L., mączniak jabłoni, parch jabłoni

The aim of the study was to assess the suitability of several apple cultivars for breeding of new genotypes resistant/low susceptible to apple scab and powdery mildew based on their general (GCA) and specific (SCA) combining abilities. Infection degree of the apple seedlings, being the progeny of 11 cultivars crossed in the model: $\$ 4$ x $\hat{\jmath} 7-4$ maternal cultivars ('Alwa', 'Golden Delicious', 'Free Redstar', 'Gold Milenium') and 7 paternal cultivars ('Glogierówka', 'Kronselka', 'Kosztela', 'McIntosh', 'Oliwka Żółta', 'Malinowa Oberlandzka', 'Koksa Pomarańczowa') by both apple pathogens was evaluated in July 2019. Significantly negative value for the GCA effect for the infection degree by apple scab was estimated for 'Free Redstar'. This indicates that this cultivar is a good donor of genes responsible for resistance to apple scab in the progeny. Negative value of GCA effect for susceptibility to powdery mildew was also stated for 'Free Redstar'. This means that this cultivar may serve as good donor of genes determining resistance/low susceptibility to powdery mildew in its progeny. Negative SCA effects for resistance/low susceptibility to apple scab, moreover, were indicated for 3 cross combinations: 'Free Redstar' x 'McIntosh', 'Alwa' x 'Malinowa Oberlandzka' and 'Alwa' $\mathrm{x}$ 'McIntosh'. This indicates that genetic interaction of both parental genotypes results in genetic determination of resistance or high tolerance to apple scab in their progeny.

Key words: apple, apple scab, Malus domestica L., powdery mildew

\section{Wstęp}

Jabłoń jest najważniejszym gatunkiem roślin sadowniczych klimatu umiarkowanego, dobrze przystosowanym do uprawy w warunkach przyrodniczych Polski. Światowa produkcja jabłek wynosi ok. 70 milionów ton. Według szacunku GUS, w 2019 r. produkcja jabłek w Polsce wyniosła $3 \mathrm{mln}$ ton. Polska jest więc największym producentem owoców tego gatunku w Unii Europejskiej, a trzecim w świecie po Chinach (35-40 mln ton) i USA (4,5-5 mln ton). W uprawie jabłoni w Polsce dominują odmiany zagraniczne, jak 'Idared', 'Szampion', 'Jonagold' czy 'Golden Delicious' (Kruczyńska, 2008; Badowska-Czubik i in., 2012). Warunkiem dalszego dynamicznego rozwoju produkcji jabłek w Polsce jest systematyczne wdrażanie do uprawy towarowej nowych, cennych odmian jabłoni, które są najważniejszym nośnikiem postępu biologicznego w produkcji sadowniczej. Tylko takie genotypy umożliwiają wdrażanie innowacyjnych technologii uprawy oraz zwiększanie konkurencyjności i opłacalności produkcji jabłek, przy zachowaniu wymogów ochrony środowiska i zasad produkcji bezpiecznej 
żywności. Dlatego hodowcy stale poszukują nowych odmian jabłoni, lepszych od będących w uprawie, które odznaczałyby się kompleksem wielu cech, często trudnych do pogodzenia ze sobą, ale decydujących o wysokich walorach produkcyjnych i użytkowych odmian, jak: zróżnicowana pora dojrzewania owoców, wysoka plenność i jakość deserowa owoców (podwyższona zawartość ekstraktu, witaminy C i kwasowości), atrakcyjna barwa i kształt owoców, zdolność owoców do dobrego i długiego przechowywania się, słaba siła wzrostu drzew oraz wysoka wytrzymałość drzew na mróz (Lewandowski i Żurawicz, 2007). Rynek konsumencki w coraz większym stopniu zainteresowany jest odmianami o jednolitej barwie skórki (zielone, żółte lub czerwone). Barwa często decyduje o jakości owoców, a w konsekwencji i ich cenie. Poszukiwane są także odmiany wykazujące dużą zdolność do samodzielnego regulowania owocowania, bez konieczności przerzedzania zawiązków, tak aby plonowały corocznie i obficie. Czynnikiem decydującym o sukcesie w uprawie jabłoni jest także tworzenie nowych odmian z wysoką odpornością lub małą podatnością drzew na parcha jabłoni (Venturia inaequalis), mączniaka jabłoni (Podosphaera leucotricha) i zarazę ogniową (Erwinia amylovora). Uprawiając odporne odmiany jabłoni, producenci jabłek mogą obniżyć koszty produkcji poprzez zmniejszenie liczby oprysków w sadach. Jest to bardzo ważny problem, zwłaszcza obecnie, gdy następuje znaczny spadek opłacalności produkcji jabłek oraz duży wzrost zainteresowania proekologicznymi metodami uprawy (Żurawicz i in., 2004; Żurawicz i Lewandowski, 2011; Żurawicz i in., 2013).

Celem badań było określenie wartości hodowlanej badanych form rodzicielskich poprzez oszacowanie efektów GCA (ogólna zdolność kombinacyjna) i SCA (specyficzna zdolność kombinacyjna) dla odporności roślin na parcha i mączniaka jabłoni w oparciu o ocenę potomstwa 28 rodzin mieszańców.

\section{Material i Metody}

Przedmiotem badań była populacja 2800 siewek jabłoni otrzymanych ze skrzyżowania 11 odmian jabłoni - 4 formy mateczne $q$ (odmiany o krótkim okresie juwenilnym - 'Alwa', 'Golden Delicious', 'Free Redstar', 'Gold Milenium') i 7 form ojcowskich ô (odmiany"stare", dzisiaj już nie uprawiane w Polsce na skalę towarową, ale znane ze specyficznego, unikalnego smaku owoców 'Glogierówka', 'Kronselka', 'Kosztela', 'McIntosh', 'Oliwka Żółta', 'Malinowa Oberlandzka', 'Koksa
Pomarańczowa') (tab. 1). Badane siewki należą do 28 kombinacji uzyskanych z krzyżowań w układzie czynnikowym $(+4 \times \bigcirc 7)$ (tab. 2). Wszystkie siewki były zaszczepione na podkładce M.9. Doświadczenie polowe posadzono jesienią 2017 w kwaterze hodowlanej w Sadzie Doświadczalnym w Dąbrowicach, w układzie losowanych bloków kompletnych, w 4 powtórzeniach, po 25 siewek na poletku, w rozstawie $3,50 \times 1,0 \mathrm{~m}$. W dniach 08-12.07.2019 r. dla każdej rośliny/siewki została wykonana ocena stopnia porażenia siewek przez parcha i mączniaka jabłoni:

1. ocena stopnia porażenia siewek przez parcha jabłoni (Venturia inaequalis) wykonana była przy zastosowaniu skali bonitacyjnej (1-5) wg Shay i Hough (1952) i Crosby i wsp. (1992), gdzie poszczególne klasy oznaczają: 1 - brak makroskopowych objawów infekcji na liściach, 2 - małe plamy parcha na liściach, grzyb nie zarodnikuje, 3 - nieregularne chlorotyczne lub nekrotyczne plamy na liściach, grzyb nie zarodnikuje, 4 - niewielkie i nieliczne plamy parcha na liściach, grzyb zarodnikuje, 5 - duże i liczne plamy parcha na liściach, grzyb zarodnikuje,

2. ocena stopnia porażenia siewek przez mączniaka jabłoni (Podosphaera leucotricha) wykonana była przy zastosowaniu skali bonitacyjnej (1-5) wg Boreckiego (1987), biorąc za podstawę powierzchnię liści pokrytą białym nalotem grzybni Podosphaera leucotricha. Poszczególne klasy oznaczają: 1 - brak objawów porażenia mączniakiem, pojedyncze liście pokryte nalotem grzybni, średnio $1 \%$, $2-$ od 1 do $10 \%$ powierzchni liści pokrytej nalotem grzybni, średnio 5\%, 3 - od 11 do 30\% powierzchni liści pokrytej nalotem grzybni, średnio $20 \%, 4$ - od 31 do $50 \%$ powierzchni liści pokrytej grzybnią, średnio $40 \%, 5$ - od 51 do $100 \%$ powierzchni liści pokrytej grzybnią, średnio $75 \%$.

Analiza statystyczna. Uzyskane dane poddano analizie, którą przeprowadzono kilkuetapowo. Na podstawie obserwacji każdej cechy na pojedynczych roślinach wyznaczono średnie arytmetyczne dla każdego powtórzenia. Średnie te użyto do ich wstępnego opracowania statystycznego metodą jednoczynnikowej analizy wariancji według układu losowanych bloków, w którym czynnikiem są rodziny mieszańców. Po stwierdzeniu istotnego zróżnicowania średnich cech u badanych mieszańców wykonano analizę wariancji dla układu czynnikowego $(\$ 4 \times 37)$ na podstawie modelu stałego, 
w celu oszacowania efektów GCA i SCA oraz ilorazu średnich kwadratów odchyleń dla GCA i SCA dla badanych cech. Szczegółową analizę istotności efektów GCA i SCA wykonano przy użyciu procedury jednoczesnej opartej na nierówności Bonferroniego. Wszystkie obliczenia, dotyczące estymacji efektów GCA i SCA w powyższym modelu, analizy wariancji oraz szczegółowego testowania jednoczesnego wykonano za pomocą programu komputerowego SERGEN, opracowanego przez naukowców z Instytutu Genetyki Roślin PAN w Poznaniu (Caliński i in., 2003).

\section{Wyniki i Dyskusja}

Wykonano badania nad wartością fenotypową populacji siewek jabłoni w oparciu o indywidualną ocenę ich porażenia przez parcha i mączniaka jabłoni. Przydatność wybranych 11 genotypów (form rodzicielskich) jabłoni do programu krzyżowań oceniono na podstawie ogólnej (GCA) i specyficznej (SCA) zdolności kombinacyjnej (Mądry i Ubysz -Borucka, 1982). Według tych autorów GCA jest to średnia wartość cechy ilościowej w potomstwie rozpatrywanej formy rodzicielskiej. Jest miarą addytywnego działania genów na tę cechę. SCA jest interakcją (współdziałaniem) obu form rodzicielskich ujawnianą w ich potomstwie, w wyniku pojedynczych kombinacji krzyżowań. Jest wynikiem nieaddytywnego działania genów (dominacji i epistazy) (Ubysz-Borucka i in., 1985).

W praktyce najwartościowsze potomstwo pod względem pożądanej cechy uzyskuje się w wyniku krzyżowania form rodzicielskich, które odznaczają się istotnymi i pozytywnymi wartościami efektów GCA (Griffing, 1956 a, b). W naszych badaniach genetycznych stwierdzono, że wśród 11 genotypów rodzicielskich jabłoni, tylko 3 odmiany: 'Free Redstar', 'Alwa' i 'Oliwka Żółta' miały istotne (na plus lub minus) wartości efektów GCA dla stopnia porażenia siewek przez parcha i mączniaka jabłoni (tab. 1). Wyniki pokazują, że istotnie różne od zera wartości efektów GCA dla stopnia porażenia siewek przez parcha jabłoni oszacowano dla odmiany 'Free Redstar'. Pomimo, że była to wartość ujemna, ale dla hodowcy oznacza to, że genotyp ten jest donorem genów warunkujących odporność lub małą podatność na parcha jabłoni u potomstwa jabłoni. Natomiast odmiany 'Alwa' i 'Oliwka Żółta' miały istotnie dodatnie efekty GCA dla tej cechy. Odmiany te użyte jako formy rodzicielskie są więc donorami genów warunkujących podatność na parcha jabłoni u siewek jabłoni. Istotnie ujemną wartość efektów GCA dla stopnia porażenia siewek przez mączniaka jabłoni oszacowano dla odmiany 'Free Redstar'. Genotyp ten jest więc donorem genów warunkujących odporność lub małą podatność na mączniaka jabłoni u potomstwa jabłoni. Natomiast odmiana 'Alwa' miała istotnie dodatni efekt GCA dla tej cechy. Odmiana ta użyta jako forma rodzicielska jest więc donorem genów warunkujących podatność na mączniaka jabłoni u potomstwa jabłoni. Nasze wyniki znajdują potwierdzenie w literaturze, która wskazuje, że genotyp 'Free Redstar' jest odmianą odporną na parcha jabłoni $\left(\mathrm{V}_{\mathrm{f}}\right)$, zaś genotypy 'Alwa' i 'Oliwka Żółta' są odmianami średnio podatnymi na tego patogena (Rejman, 1994; Żurawicz, 2003; Lewandowski i Żurawicz, 2007; Żurawicz i in., 2013). W badaniach prowadzonych w latach 2004-2006 w warunkach polowych przez Lewandowskiego i Żurawicza (2007), na odmianie 'Free Redstar' nie obserwowano żadnych objawów mączniaka jabłoni na liściach i owocach. Genotyp ten jest więc odmianą odporną lub mało podatną na tego patogena.

Zróżnicowanie efektów SCA w obrębie badanego układu krzyżowań świadczy o dużym znaczeniu genetycznego współdziałania obu form rodzicielskich $\mathrm{w}$ uwarunkowaniu cech $\mathrm{w}$ potomstwie (Baker, 1978). Zatem efekty SCA ujawniaja się tylko w niektórych kombinacjach krzyżowań i mogą poprawiać lub pogarszać wartość analizowanych cech u potomstwa. Z literatury wiadomo, że wysokie wartości efektów SCA, stwierdzone w poszczególnych populacjach mieszańcowych, dotyczą najczęściej pojedynczych cech użytkowych. Sprawia to, że uzyskanie nowych odmian o poprawionych kilku cechach jednocześnie jest bardzo trudne lub niemożliwe (Spangelo i in., 1971; Hortyński, 1987; Simpson i Sharp, 1988; Żurawicz i in., 1996; Mądry i in., 2004; Masny $i$ in., 2008; Pluta $i$ in., 2008). W naszych badaniach nad zdolnością kombinacyjną 11 form rodzicielskich (4 matecznych i 7 ojcowskich) stwierdzono istotne (dodatnie lub ujemne) wartości efektów SCA dla stopnia porażenia siewek przez parcha i mączniaka jabłoni (tab. 2). Dla stopnia porażenia siewek przez parcha jabłoni, wartość ujemną efektów SCA uzyskano dla 3 rodzin mieszańców: 'Free Redstar' × 'McIntosh', 'Alwa' × 'Malinowa Oberlandzka' i 'Alwa' $\times$ 'McIntosh'. Oznacza to, że w przypadku tych rodzin genetyczne współdziałanie obu genotypów rodzicielskich warunkuje odporność lub małą podatność roślin na parcha jabłoni. Wartość dodatnią efektów SCA dla tej cechy uzyskano dla 6 rodzin mieszańców: 'Free Redstar' $\times$ 'Kosztela', 'Free Redstar' $\times$ 'Malinowa Oberlandzka', 'Gold Milenium' $\times$ 'McIntosh', 
'Alwa' × 'Kronselska', 'Alwa' × 'Koksa Pomarańczowa' i 'Golden Delicious' $\times$ 'Oliwka Żółta'. Zatem należy oczekiwać, że mieszańce należące do tych rodzin będą charakteryzować się podatnością na parcha jabłoni. Dla stopnia porażenia siewek przez mączniaka jabłoni, wartość dodatnią efektów SCA uzyskano dla 3 rodzin mieszańców: 'Gold Milenium' × 'Malinowa Oberlandzka', 'Alwa' $\times$ 'Kronselska' i 'Alwa' $\times$ 'Koksa Pomarańczowa'. Zatem należy oczekiwać, że mieszańce należące do tych rodzin będą charakteryzować się podatnością na mączniaka jabłoni.

Dotychczas nie prowadzono w Polsce badań nad zdolnością kombinacyjną genotypów rodzicielskich jabłoni używanych w programach hodowli, o czym świadczy brak stosownej literatury. Literatura zagraniczna dotycząca tych zagadnień i dla tego gatunku uprawnego jest także bardzo ograniczona.
Badania takie wykonano jedynie w Rumunii (Dan i in., 2015). Brak takich badań jest związany głównie z trudnościami wykonania kompletnego programu krzyżowań (układ dialleliczny lub czynnikowy) i uzyskania dużej populacji siewek do oceny fenotypowej. Ponadto barierą do prowadzenia tego typu badań jest także duża pracochłonność wykonania indywidualnej obserwacji, pomiarów i oceny wielu cech użytkowych dla kilku tysięcy siewek. Związane to jest również z dużymi nakładami finansowymi.

\section{Wnioski}

1. Wstępne wyniki badań pokazują, że badane genotypy rodzicielskie jabłoni różnią się zdolnością kombinacyjną (efekty GCA i SCA) pod względem stopnia porażenia siewek przez parcha i mączniaka jabłoni.

Tabela 1

Table 1

Ocena efektów GCA dla stopnia porażenia przez parcha i mączniaka jabłoni siewek 11 odmian jabłoni krzyżowanych w układzie czynnikowym $\left(+4 \times{ }^{\top} 7\right)$, Dąbrowice, 2019

Estimates of GCA effects for the infection level by apple scab and powdery mildew of 11 apple genotypes crossed in the factorial design $(+4 \times \overbrace{}^{7} 7)$, Dąbrowice, 2019

\begin{tabular}{|c|c|c|c|c|c|}
\hline \multirow{3}{*}{$\begin{array}{c}\text { Nr matki } \\
\text { lub ojca } \\
\text { Maternal } \\
\text { or paternal } \\
\text { No. }\end{array}$} & \multirow{3}{*}{$\begin{array}{l}\text { Formy rodzicielskie } \\
\text { Parental forms }\end{array}$} & \multicolumn{4}{|c|}{$\begin{array}{l}\text { Stopień porażenia siewek jabłoni } \\
\text { Infection level of apple seedlings }\end{array}$} \\
\hline & & \multicolumn{2}{|c|}{$\begin{array}{l}\text { Parch jabłoni } \\
\text { Apple scab }\end{array}$} & \multicolumn{2}{|c|}{$\begin{array}{l}\text { Mączniak jabłoni } \\
\text { Powdery mildew }\end{array}$} \\
\hline & & $\begin{array}{l}\text { Ocena efektu } \\
\text { głównego } \\
\text { Main effect } \\
\text { evaluation }\end{array}$ & $\begin{array}{c}\text { Statystyka F dla } \\
\text { efektu głównego } \\
\text { F statistics for the } \\
\text { main effect }\end{array}$ & $\begin{array}{l}\text { Ocena efektu } \\
\text { głównego } \\
\text { Main effect } \\
\text { evaluation }\end{array}$ & $\begin{array}{l}\text { Statystyka F dla } \\
\text { efektu głównego } \\
\text { F statistics for the } \\
\text { main effect }\end{array}$ \\
\hline \multicolumn{6}{|c|}{$\begin{array}{l}\text { Analiza względem form matecznych }-\uparrow \\
\text { Analysis in relation to maternal forms - } \uparrow\end{array}$} \\
\hline 1 & Free Redstar & $-0,131 * *$ & 17,14 & $-0,064 * *$ & 12,96 \\
\hline 2 & Gold Milenium & 0,004 & 0,02 & $-0,039$ & 4,84 \\
\hline 3 & Alwa & $0,140 * *$ & 19,55 & $0,082 * *$ & 21,16 \\
\hline 4 & Golden Delicious & $-0,013$ & 0,18 & 0,021 & 1,44 \\
\hline \multicolumn{6}{|c|}{ 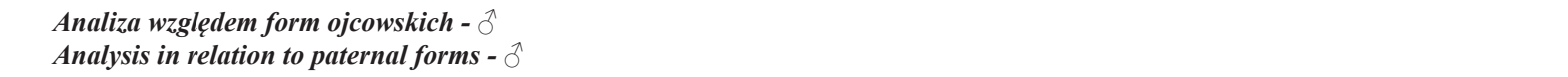 } \\
\hline 1 & Glogierówka & $-0,182$ & 6,78 & $-0,064$ & 1,52 \\
\hline 2 & Kosztela & 0,099 & 2,01 & $-0,046$ & 0,76 \\
\hline 3 & Malinowa Oberlandzka & $-0,038$ & 0,30 & 0,079 & 2,33 \\
\hline 4 & Kronselska & $-0,157$ & 5,05 & $-0,064$ & 1,52 \\
\hline 5 & Oliwka Żólta & $0,287 * *$ & 16,79 & 0,048 & 0,86 \\
\hline 6 & Koksa Pomarańczowa & $-0,063$ & 0,82 & $-0,033$ & 0,40 \\
\hline 7 & McIntosh & 0,055 & 0,63 & 0,079 & 2,33 \\
\hline
\end{tabular}

Objaśnienie: * - wartości istotnie różne od średniej wartości ogólnej przy poziomie $\alpha=0,05$

**_wartości istotnie różne od średniej wartości ogólnej przy poziomie $\alpha=0,01$

Explanation: * - values significantly different from the average general value at the level of $\alpha=0.05$

** - values significantly different from the average general value at the level of $\alpha=0.01$ 
2. Oszacowane efekty GCA i SCA 11 form rodzicielskich przyjmują wartości dodatnie i ujemne. Genotypy rodzicielskie jabłoni użyte w krzyżowaniach w różnym stopniu przekazują odporność/podatność na parcha i mączniaka jabłoni u potomstwa siewek jabłoni.

Badania finansowano ze środków projektu MRiRW: Badania podstawowe na rzecz postepu biologicznego w produkcji roślinnej, decyzja HOR. hn.802.4.2019 z dnia 14.05.2019 r., Zadanie $n r 71$.

Tabela 2

Table 2

Ocena efektów SCA dla stopnia porażenia przez parcha i mączniaka jabłoni siewek należących do 28 rodzin mieszańcowych uzyskanych ze skrzyżowania 11 odmian jabłoni w układzie czynnikowym $(+4 \times 37)$, Dąbrowice, 2019

Estimates of SCA effects for the infection degree by apple scab and powdery apple seedlings belonging to 28 hybrid families obtained from 11 apple genotypes crossed in the factorial design $(+4 \times 17)$, Dąbrowice, 2019

\begin{tabular}{|c|c|c|c|c|c|}
\hline \multirow{3}{*}{$\begin{array}{l}\text { Nr rodziny } \\
\text { Family } \\
\text { No. }\end{array}$} & \multirow{3}{*}{$\begin{array}{c}\text { Rodziny mieszańcowe } \\
\text { Hybrid families }\end{array}$} & \multicolumn{4}{|c|}{$\begin{array}{c}\text { Stopień porażenia siewek } \\
\text { Infection level of apple seedlings }\end{array}$} \\
\hline & & \multicolumn{2}{|c|}{$\begin{array}{l}\text { Parch jabłoni } \\
\text { Apple scab }\end{array}$} & \multicolumn{2}{|c|}{$\begin{array}{l}\text { Mączniak jabłoni } \\
\text { Powdery mildew }\end{array}$} \\
\hline & & $\begin{array}{l}\text { Ocena efektu } \\
\text { głównego } \\
\text { Main effect } \\
\text { evaluation }\end{array}$ & $\begin{array}{l}\text { Statystyka } \\
\text { F dla efektu } \\
\text { głównego } \\
\text { F statistics for } \\
\text { the main effect }\end{array}$ & $\begin{array}{l}\text { Ocena efektu } \\
\text { głównego } \\
\text { Main effect } \\
\text { evaluation }\end{array}$ & $\begin{array}{l}\text { Statystyka } \\
\text { F dla efektu } \\
\text { głównego } \\
\text { F statistics for } \\
\text { the main effect }\end{array}$ \\
\hline 1 & Free Redstar $\times$ Glogierówka & $-0,031$ & 0,16 & $-0,196$ & 7,19 \\
\hline 2 & Free Redstar $\times$ Kosztela & $0,350 * *$ & 20,31 & $-0,096$ & 1,72 \\
\hline 3 & Free Redstar $\times$ Malinowa Oberlandzka & $0,306 * *$ & 15,55 & $-0,146$ & 3,98 \\
\hline 4 & Free Redstar $\times$ Kronselska & $-0,125$ & 2,59 & $-0,096$ & 1,72 \\
\hline 5 & Free Redstar $\times$ Oliwka Żółta & $-0,087$ & 1,27 & $-0,196$ & 7,19 \\
\hline 6 & Free Redstar $\times$ Koksa Pomarańczowa & $-0,106$ & 1,87 & $-0,196$ & 7,19 \\
\hline 7 & Free Redstar $\times$ McIntosh & $-0,306 * *$ & 15,55 & $-0,096$ & 1,72 \\
\hline 8 & Gold Milenium $\times$ Glogierówka & $-0,117$ & 2,27 & $-0,096$ & 1,72 \\
\hline 9 & Gold Milenium $\times$ Kosztela & $-0,186$ & 5,72 & $-0,071$ & 0,94 \\
\hline 10 & Gold Milenium $\times$ Malinowa Oberlandzka & 0,196 & 6,34 & $0,254 *$ & 12,18 \\
\hline 11 & Gold Milenium $\times$ Kronselska & $-0,211$ & 7,36 & $-0,021$ & 0,08 \\
\hline 12 & Gold Milenium $\times$ Oliwka Żółta & $-0,173$ & 4,97 & $-0,221$ & 9,15 \\
\hline 13 & Gold Milenium $\times$ Koksa Pomarańczowa & $-0,142$ & 3,34 & $-0,121$ & 2,73 \\
\hline 14 & Gold Milenium $\times$ McIntosh & $0,633 * *$ & 66,44 & 0,029 & 0,16 \\
\hline 15 & Alwa $\times$ Glogierówka & 0,022 & 0,08 & 0,204 & 7,86 \\
\hline 16 & Alwa $\times$ Kosztela & 0,029 & 0,14 & $-0,046$ & 0,39 \\
\hline 17 & Alwa $\times$ Malinowa Oberlandzka & $-0,440 * *$ & 32,12 & $-0,096$ & 1,72 \\
\hline 18 & Alwa $\times$ Kronselska & $0,254 *$ & 10,66 & $0,404 * *$ & 30,77 \\
\hline 19 & Alwa $\times$ Oliwka Żółta & $-0,009$ & 0,01 & 0,179 & 6,06 \\
\hline 20 & Alwa $\times$ Koksa Pomarańczowa & $0,422 * *$ & 29,57 & $0,254 *$ & 12,18 \\
\hline 21 & Alwa $\times$ McIntosh & $-0,278 *$ & 12,78 & 0,129 & 3,15 \\
\hline 22 & Golden Delicious $\times$ Glogierówka & 0,126 & 2,63 & 0,154 & 4,49 \\
\hline 23 & Golden Delicious $\times$ Kosztela & $-0,193$ & 6,17 & $-0,146$ & 3,98 \\
\hline 24 & Golden Delicious $\times$ Malinowa Oberlandzka & $-0,062$ & 0,63 & 0,079 & 1,19 \\
\hline 25 & Golden Delicious $\times$ Kronselska & 0,082 & 1,12 & 0,204 & 7,86 \\
\hline 26 & Golden Delicious $\times$ Oliwka Żólta & $0,270 *$ & 12,05 & $-0,096$ & 1,72 \\
\hline 27 & Golden Delicious $\times$ Koksa Pomarańczowa & $-0,174$ & 5,03 & $-0,121$ & 2,73 \\
\hline 28 & Golden Delicious $\times$ McIntosh & $-0,049$ & 0,40 & 0,154 & 4,49 \\
\hline
\end{tabular}

Objaśnienie: * - wartości istotnie różne od średniej wartości ogólnej przy poziomie $\alpha=0,05$

**-wartości istotnie różne od średniej wartości ogólnej przy poziomie $\alpha=0,01$

Explanation: * - values significantly different from the average general value at the level of $\alpha=0.05$

** - values significantly different from the average general value at the level of $\alpha=0.01$ 


\section{Literatura}

Badowska-Czubik, T., Bielicki, P., Bryk, H., Buczek, M., Cieślińska, M., Kołtowski, Z., Kruczyńska, D., Lisek, J., Meszka, B., Morgaś, H., Rabcewicz, J., Rutkowski, K., Sekrecka, M., Sobiczewski, P. J., Treder, W., Wawrzyniak, A., Wójcik, P. (2012). Jabłoń. Hortpress, 216 p.

Baker, R. J. (1978). Issues in diallel analysis. Crop Science, 18 (4): 533-536.

Borecki,Z.(1987). Field susceptibility of 13 scab-resistant apple cultivarstoapplepowderymildew[Podosphaeraleucotricha (Ell. et Ev.) Salmon]. Acta Agrobotanica, 40 (1-2): 87-98.

Caliński, T., Czajka, S., Kaczmarek, Z., Krajewski, P. (2003). Podręcznik użytkowania programu SERGEN 4. Metodyka statystyczna i obsługa programu SERGEN (Wersja 4 dla Windows) przeznaczonego do serii doświadczeń odmianowych i genetyczno-hodowlanych. Wyd. IGR PAN w Poznaniu. ss 77.

Crosby, J. A., Janick, J., Pecknold, P. C., Korban, S. S., O'Connor, P. A., Ries, S. M., Goffreda, J., Voordeckers, A. (1992). Breeding apples for scab resistance: 1945-1990. Fruit Varieties Journal, 46: 145-166.

Dan, C., Sestras, A. F., Bozdog, C., Sestras, R. E. (2015). Estimation of genetic effects implied in apple inheritance of quantitative traits. Journal of Horticulture, Forestry and Biotechnology, 19(1): 85-90.

Griffing, B. (1956)a. A generalised treatments of diallel crosses in quantitative inheritance. Heredity, 10: 31-50.

Griffing, B. (1956)b. Concept of general and specific combining ability in relation to diallel crossing systems. Austr. J. Biol. Sci., 9: 463-493.

Hortyński, J. A. (1987). Dziedziczenie niektórych cech ilościowych truskawki (Fragaria $\times$ ananassa Duch.). Metody i problemy oszacowań. AR, Lublin: 1-98.

Kruczyńska, D. (2008). Jabłonie - nowe odmiany. Hortpress, Warszawa, $214 \mathrm{p}$.

Lewandowski, M., Żurawicz, E. (2007). Plonowanie nowych parchoodpornych odmian jabłoni hodowli Instytutu Sadownictwa i Kwiaciarstwa w Skierniewicach na różnych typach podkładek. Roczniki AR Poznań CCCLXXXIII, Ogrodnictwo, 41: 333-337.

Masny, A., Mądry, W., Żurawicz, E. (2008). Combining ability for important horticultural traits in medium and latematuring strawberry cultivars. Journal of Fruit and Ornamental Plant Research, 16: 133-152.
Mądry, W., Ubysz-Borucka, L. (1982). Biometryczna analiza zdolności kombinacyjnej w niekompletnym układzie diallel cross. Cz. I. Model stały dla cech ilościowych. Rocz. Nauk Roln. Ser. A, 105: 9-27.

Mądry, W., Krajewski, P., Pluta, S., Żurawicz, E. (2004). Wielocechowa analiza wartości hodowlanej i zróżnicowania genetycznego odmian porzeczki czarnej (Ribes nigrum L.) na podstawie efektów ogólnej zdolności kombinacyjnej. Acta Scient. Polon. Ser. Hortorum. Cultus, 3: 93-109.

Pluta, S., Mądry, W., Żurawicz, E. (2008). General combining ability of selected blackcurrant (Ribes nigrum L.) genotypes in breeding for dessert quality fruit. Acta Hort., 777: 57-62.

Rejman, A. (1994). Jabłonie, W: Rejman, A. (ed.). Pomologia - Odmianoznawstwo Roślin Sadowniczych. PWRiL, Warszawa, 19-130.

Shay, J. R., Hough, L. F. (1952). Evaluation of Apple Scab Resistance in Selections of Malus. American Journal of Botany, 39 (4): 288-297.

Simpson, D. W., Sharp, D. S. (1988). The inheritance of fruit yield and stolon production in everbearing strawberries. Euphytica, 38: 65-74.

Spangelo, L. P., Watkins, R., Hsu, C. S., Fejer, S. O. (1971). Combining ability analysis in the cultivated strawberry. Can. J. Plant Sci., 51: 377-383.

Ubysz-Borucka, L., Mądry, W., Muszyński, S. (1985). Podstawy statystyczne genetyki cech ilościowych w hodowli roślin. Wydawnictwo SGGW-AR, Warszawa: $220 \mathrm{~s}$.

Żurawicz, E., Mądry, W., Pluta, S. (1996). Variation and heritability of economically important traits in black currant (Ribes nigrum L.) evaluated in a diallel cross design. Euphytica, 91: 219-224.

Żurawicz, E. (2003). Pomologia - odmianoznawstwo roślin sadowniczych, aneks. Wyd. PWRiL, Warszawa.

Żurawicz, E., Lewandowski, M., Broniarek-Niemiec, A., Rutkowski, K. (2004). Preliminary results on the production value of new scab-resistant apple cultivars bred at the Research Institute of Pomology and Floriculture (RIPF), Skierniewice, Poland. Acta Hort., 663: 879-882.

Żurawicz, E., Lewandowski, M. (2011). Nowe polskie odmiany odporne na parcha jabłoni. Sad Nowoczesny, 4: 23-25.

Żurawicz, E., Lewandowski, M., Pruski, K. (2013). Productivity of selected Polish scab resistant apple cultivars grown on different rootstocks. Acta Hort., 976: 141-146. 